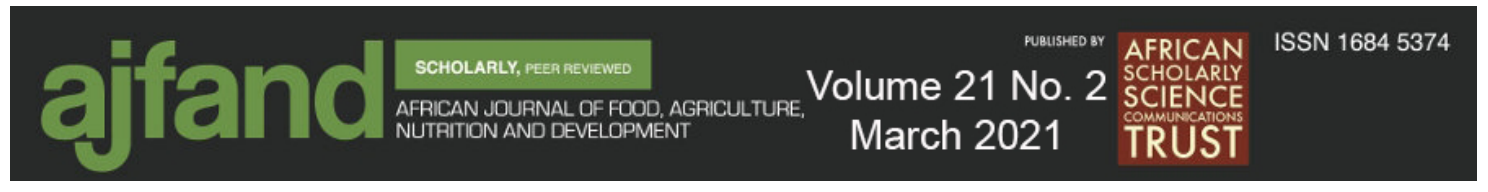

Afr. J. Food Agric. Nutr. Dev. 2021; 21(2): 17604-17620

https://doi.org/10.18697/ajfand.97.16050

\title{
FACTORS AFFECTING THE COMMERCIALIZATION OF FOOD LEGUMES IN NORTH CAMEROON
}

$$
\text { Vunyingah } \mathbf{M}^{1^{*}} \text {, Satou } \mathrm{KN}^{1} \text {, Barbi } \mathbf{M}^{1} \text {, }
$$
Kouebou $\mathrm{C}^{1}$ and Ko APMD ${ }^{1}$

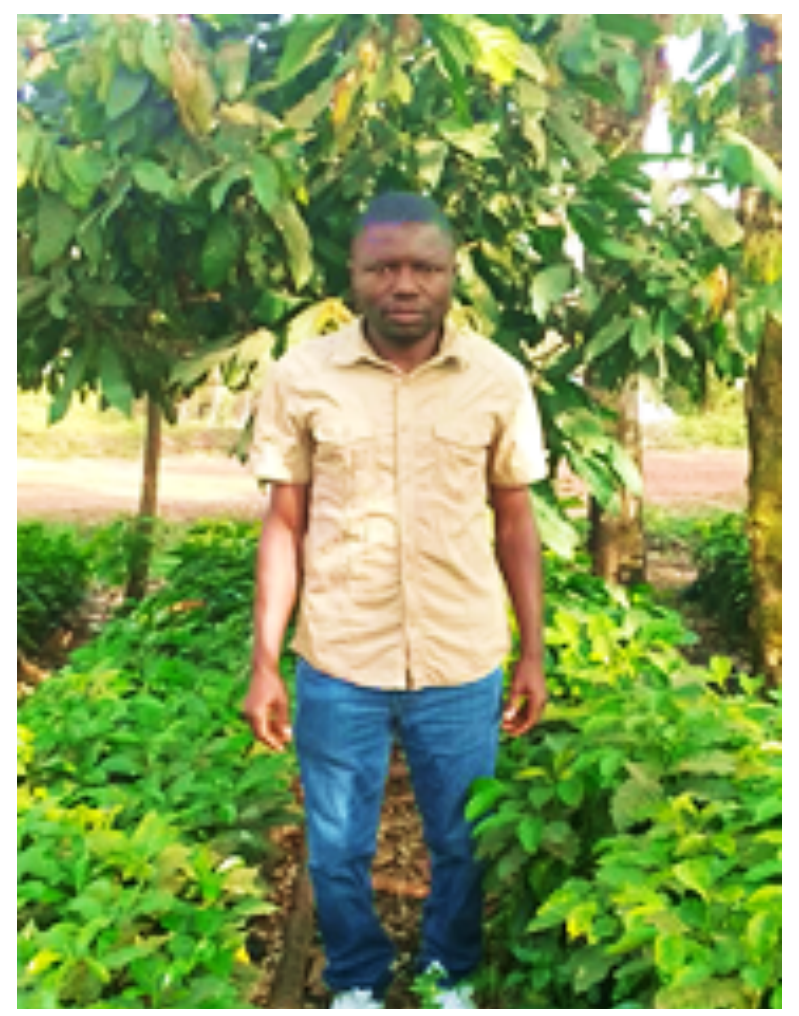

Vunyingah Michael

*Corresponding author email: bumunangmike@yahoo.co.uk

${ }^{1}$ Institute of Agricultural Research for Development (IRAD) - P. O. Box 415, Garoua, Cameroon 


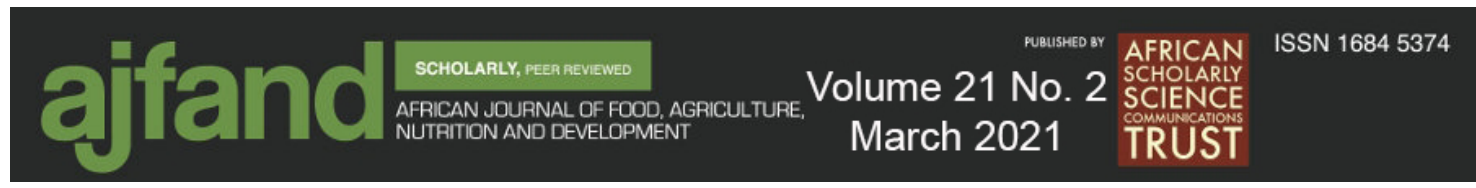

\begin{abstract}
The study focused on factors affecting the commercialization of food legumes cowpeas (Vigna unguiculata), bambara groundnuts (Vigna subterranea), groundnuts (Arachis hypogaea) and soybeans (Glycine max) in two departments (Benoué and Mayo-Louti) of the North Region of Cameroon. Qualitative and quantitative methods were used to collect data. Qualitative methods involved focus group discussions and direct observations. A structured interview guide was administered in major peri-urban and urban markets to get supportive quantitative data. The respondents were selected using purposive sampling technique. A content analysis was conducted and quantitative data was analyzed with the aid of XLSTAT 2007 software and Excel. A cross-section of the age and gender population was involved in the marketing of food legumes. Women constituted more than $80 \%$ in the retail sector on peri-urban markets. The study found that $100 \%$ of the vendors had never got any form of training on business management before engaging into the sector. Socio-cultural factors were determinant factors that impacted negatively in promoting an entrepreneurial culture among women. The marginalization of women, the restriction of land ownership by traditional tenure and poor distribution of land for agriculture were some of the main constraints faced by women. The impediments of women's empowerment include their lack of access to the decisionmaking process, low participation in local governance and limited access to technology inputs and credit. Traditional practices forbid women and girls to have or manage large amounts of money. Such restrictions have serious consequences on agricultural production. Instead of exploiting the productive capacity of women at all levels, including food production and transformation, some of the traditions simply stifle their potential energies. In addition to socio-cultural factors, major bottlenecks faced in the production and commercialisation of food legumes includes social structural and institutional, agronomic, natural (biotic and abiotic stress) and climatic factors. Development of intervention strategies through exogenous innovation techniques might act as an incentive for smallholder farmers to invest more of their land and energy in cultivation of food legumes. More attention should be focused on market research and development with crop improvement programmes that are economically profitable, if food legumes are to continue making a greater contribution to the household income, nutrition and sustainable development in North Cameroon.
\end{abstract}

Key words: Food legumes, Nutrition, Household income, Commercialization, Sustainable development, North Cameroon 


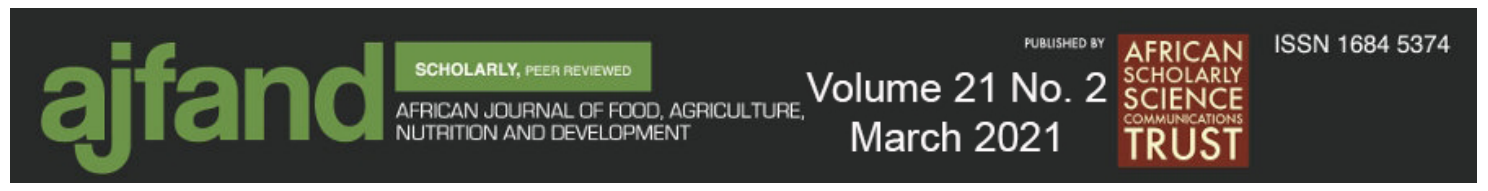

\section{INTRODUCTION}

Food legumes are important components of agricultural food crops consumed in developing countries and vital for achieving food and nutritional security for millions of poor households especially in sub-Saharan Africa and Asia. Food legumes complement cereal crops as a source of protein and minerals, and serve as rotation crops with cereals, reducing soil pathogens and supplying nitrogen to cereal crops [1, $2,3]$. Prices of food legumes are high and they are increasingly grown to supplement farmers' incomes [1]. Faced with the challenge of decreasing soil fertility and price increase of imported fertilizers, crop rotation and fallow including food legumes constitute an important alternative for sustainable management of natural resources [4].

In the cotton and cereal cropping systems in the sub-Saharan zone, the presence of nitrogen fixing food legumes reduces the need for nitrogen fertilizer. Food legumes equally permit to reduce the nitrogen fertilizer dose necessary for cereal and cotton growing for the following farming season. Groundnuts and soybeans are part of legume grains whose adoption of improved varieties is strong considering their use and multiple agronomic advantages through production of biomass destined for humans and animals, and improvement of the soil (fixing of biological nitrogen, efficient utilisation of phosphorus and fertilizer) [4]. Research on food legumes (groundnuts and soybeans) has been carried out in Cameroon in collaboration with the international community $[6,7,8,9]$. Research and development of the functional chains of food legumes especially African species (cowpea and bambara groundnuts) is thin in sub-Saharan Africa $[3,5,10]$.

The North is one of the regions mostly affected by malnutrition and food insecurity in Cameroon. Most households have difficulty securing food and suffer from nutrition deficiency (protein and fat). Food legumes such as groundnuts, cowpeas, soybeans, and bambara groundnuts could be an alternative to improve the nutrition of humans and animals, and increase the output of crops used in rotation such as sorghum (Sorghum bicolo), cotton (Gossypium spp) and maize. These food legumes reduce the development of weeds in an intercropping system and, thus, could be a source of revenue for smallholder farmers who are discouraged with cotton production, a principal cash crop in North Cameroon. The study focused on cowpeas (Vigna unguiculata), bambara groundnuts (Vigna subterranea), groundnuts (Arachis hypogaea) and soybeans (Glycine max) which are commonly cultivated and marketed by smallholder farmers in North Cameroon. In the production zone, the migrant ethnic groups (Guidar, Lamé, Daba Moundang, Mafa, Gambaye, Toupouri, Massa, Mboum, Gemsegue, Margui represented approximately $75 \%$ of those involved. These migrants come from the extreme North region and Chad. The Fulani and Fali represent about $25 \%$ of actors involved in marketing and transportation. 


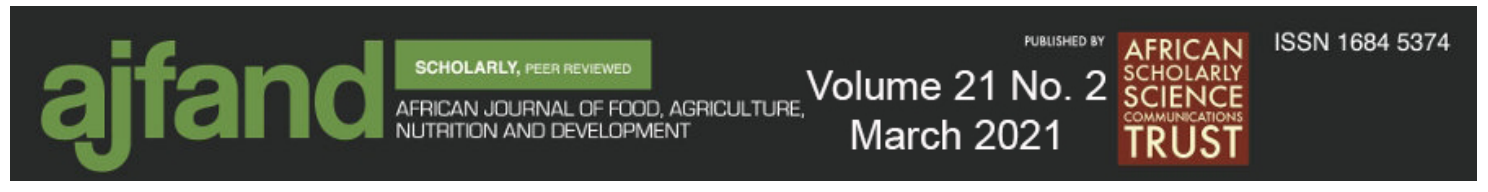

\section{Situating the zone and study area}

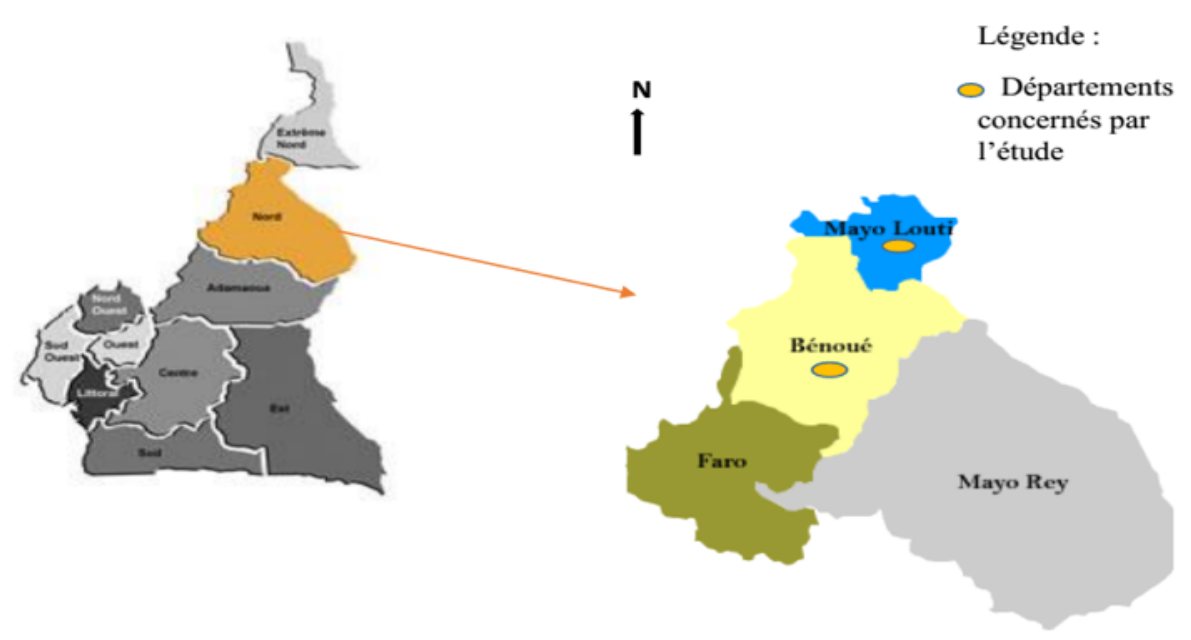

Sketch map of the Departments in the North Region [11]

The Sudano-Sahelian climatic conditions prevail, being typically humid with high precipitation oscillating around $950 \mathrm{~mm}$ annually in North Cameroon. Mayo-Louti has a classical Sudano-Sahelian climate with six months of rainy season with an average of $800 \mathrm{~mm}$ annual precipitation. The Mayo-Louti forms part of the Sudano-Sahelian intermediary between Sahelo-Sudano of Diamaré (600 to $900 \mathrm{~mm}$ rainfall) and Sudano-Guinean climate of Adamawa (1400 to $1700 \mathrm{~mm}$ rainfall). The Benoué area is characterized by scanty rainfall and short rainy season- June to October (500-950 $\mathrm{mm}$ rainfall)- and temperatures oscillating around $30^{\circ} \mathrm{C}$. $[12,13]$. The principal cereal and legume crops include maize, sorghum, millet, groundnuts, cowpea, bambara groundnuts and soybeans; cotton is the main cash crop. Climate change had detrimental and beneficial consequences on agricultural production especially in the northern zone of Cameroon in the past years [14].

\section{MATERIALS AND METHODS}

The study used a participatory approach in order to have an in-depth understanding of the research problem. Secondary sources of data involved internet, articles, books and reports. The main purpose of participatory techniques is to enable development practitioners, government officials, and local people to work together to plan context appropriate program. The main concern of the study was to evaluate, from a community perspective, the factors that hinder the commercialisation of food legumes and to propose strategic measures to improve the production and commercialization of legumes for food and nutritional security in the study area. A research protocol involving the thematic issues was handed to the various sub-divisional delegates of agriculture beforehand to inform the co-researchers on the topic for discussion. Qualitative research methods such as key informant interviews, focus group discussions and direct observation formed the core of data collection methods, while an interview guide was administered to the research sample in an effort to collect supportive quantitative data. 
Focus group discussions were conducted with participants from selected groups by sub-divisional delegates from the Ministry of Agriculture and Rural Development (MINADER) in Tcheboa, Lagdo, Mayo-Oulo, Guider and Figuil sub-divisions in the Benoue and Mayo-Louti Divisions, respectively. In Benoue division, a total of 30 participants were involved in the group discussions while in Mayo-Louti Division, a total of 23 participants were involved. The people included were known to have been involved in specific experiences related to the research problem (production, commercialisation and transformation of food legumes). A focus group discussion is a semi-structured interview in which the discussant knows in advance the topic to be covered. An interview guide was administered on weekly market days in peri-urban and urban markets. The Ngong and Guider markets are convergent points for traders and retailers from the neighbouring villages and traders from the urban areas and neighbouring countries. Djefatou, Lainde Massa, Badankali, Boumedje, Bibemi, Baila, Gouna are production zones in the Benoué division. Vendors that converge at the Guider market are from the nearby villages (Dourum, Damdogo, Gaval, Dourbeye, Bataou, Mailo, Worolala, Mosgoy, Lauggeré, Sorawel and Boula-Ibi), which are production zones in the Mayo-Louti Division.

A purposive sample in the form of an interview guide was administered to 100 vendors in Ngong, Guider, Ouro labo and Garoua market. The snowballing technique was also used in identification of key informants (wholesalers). A purposive sample is a non-representative subset of some larger population, and is constructed to serve a specific need or purpose. A researcher may have a specific group in mind, such as traditional healers. It may not be possible to specify the population. They would not all be known, and access may be difficult. The researcher will thus attempt to zero in on the target group, interviewing whoever is available [15].

In order to ensure maximum participation, the study was conducted in Fulfuldé and French languages. Interview and observation notes were typed and a content analysis conducted. In content analysis, researchers/evaluators classify key ideas in a written communication (report, article, or recorded information). In this study, we focused on analysing words. It is a systematic, research method for analysing textual information in a standardized way that allows evaluators to make inferences about the information. The central idea in content analysis is that the many words of the text are classified into much fewer content categories. Quantitative data from the structured interview guide were checked, coded and analysed using XLSTAT 2007 statistical software.

\section{RESULTS}

\section{The socio-economic and demographic characteristics of respondents}

In order to describe the socio-economic and demographic characteristics of the respondents, they were asked through an interview guide to indicate their age group, marital status, educational level, identification of food legume sold and forms of training received prior/during entrepreneurial activities. The socio-economic characteristics were important to establish correlations with exogenous marketing 


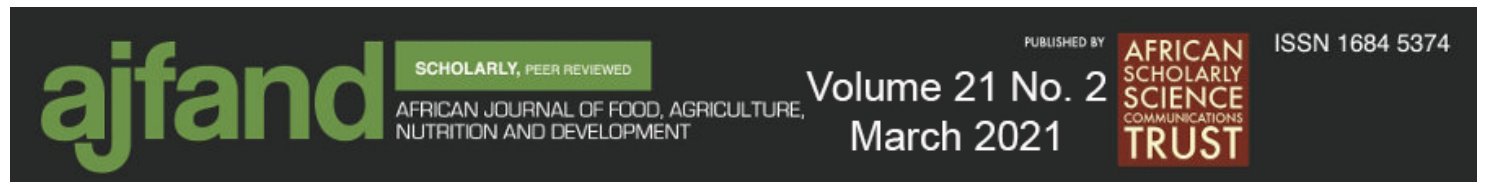

knowledge, use of phytosanitary treatment, capital, and access levels to improved varieties of food legumes. Figures 1 and 2 show the demographic and socio-economic characteristics of vendors in the study areas.

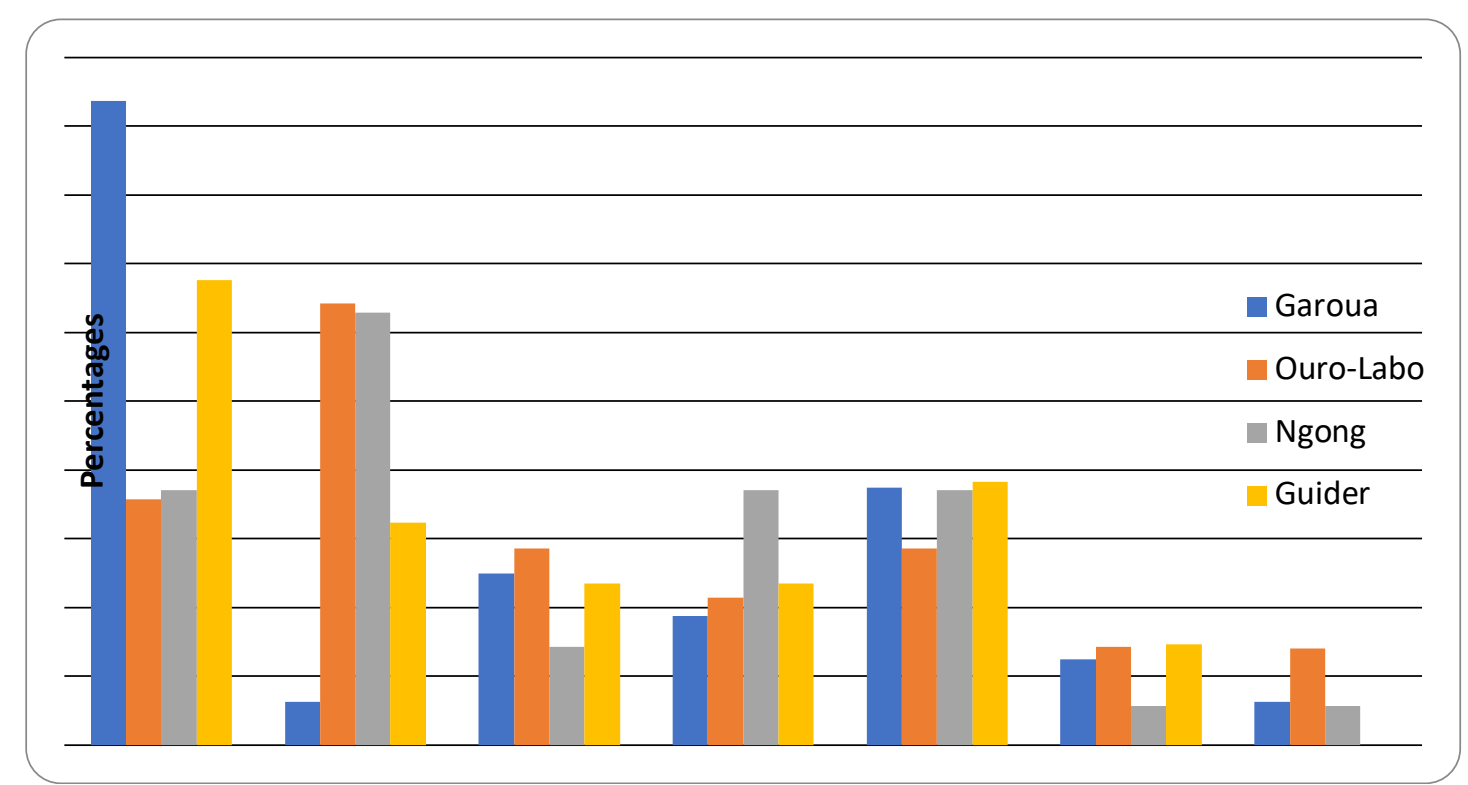

Figure 1: Age and gender distribution of respondents

Figure 1 shows that a cross-section of the age and gender population was involved in the marketing of food legumes. There was a significant percentage $(95 \%)$ of male vendors in the Garoua urban market. Observations showed women constituted more than $80 \%$ in the retail sector in peri-urban markets. Figure 2 shows the educational level and marital status of respondents.

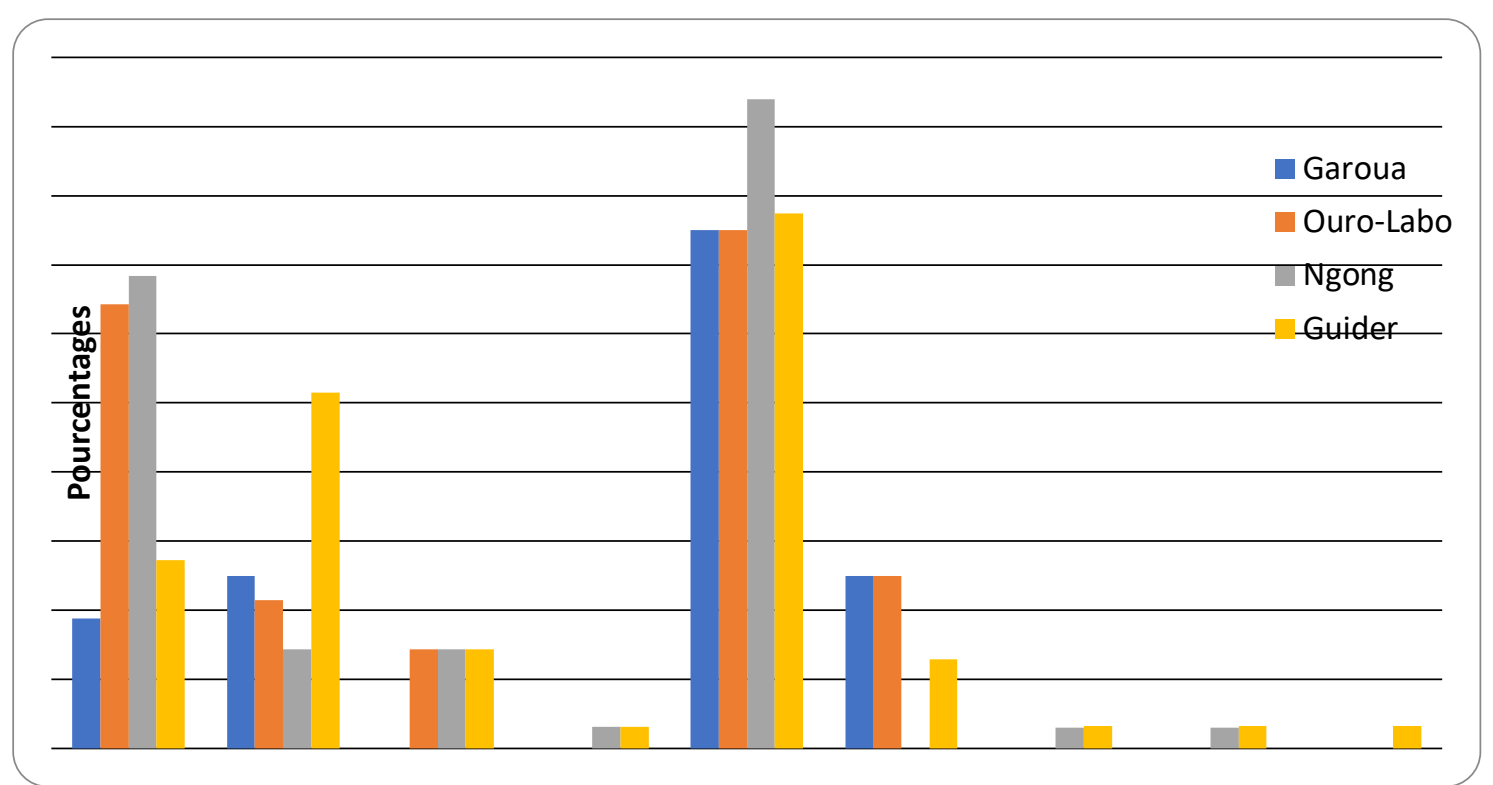

Figure 2: Educational level and marital status of respondents 


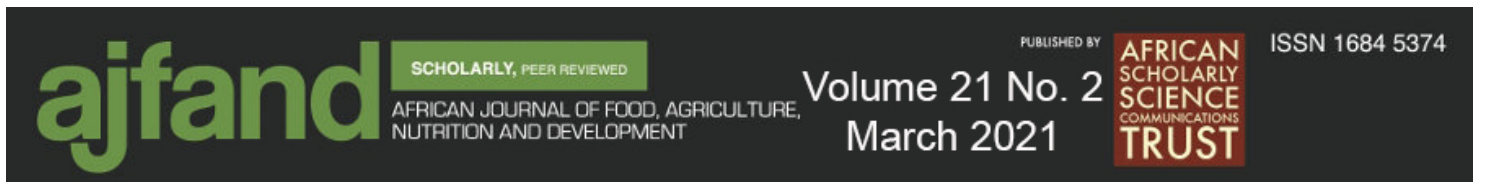

Figure 2 shows a significant percentage of vendors in the peri-urban markets never attained formal education, that is $65 \%$ in Ouro-Labo and 68\% in Ngong. However, in Guider market, $51 \%$ had primary level of education. An insignificant percentage $(15 \%)$ and $5 \%$ had secondary and tertiary levels of education. A significant percentage $(60 \%)$ of the vendors were married while $100 \%$ of respondents never received exogenous training on marketing. This situation could considerably affect their bargaining power relating to other actors in the channel who attained a certain level of formal education. The study found that $100 \%$ of vendors had never had any form of training on business management before engaging in the sector. Some vendors mixed local and improved varieties of African species (cowpeas) of food legumes. This raises ethical, moral and legal questions in the context of international practices.

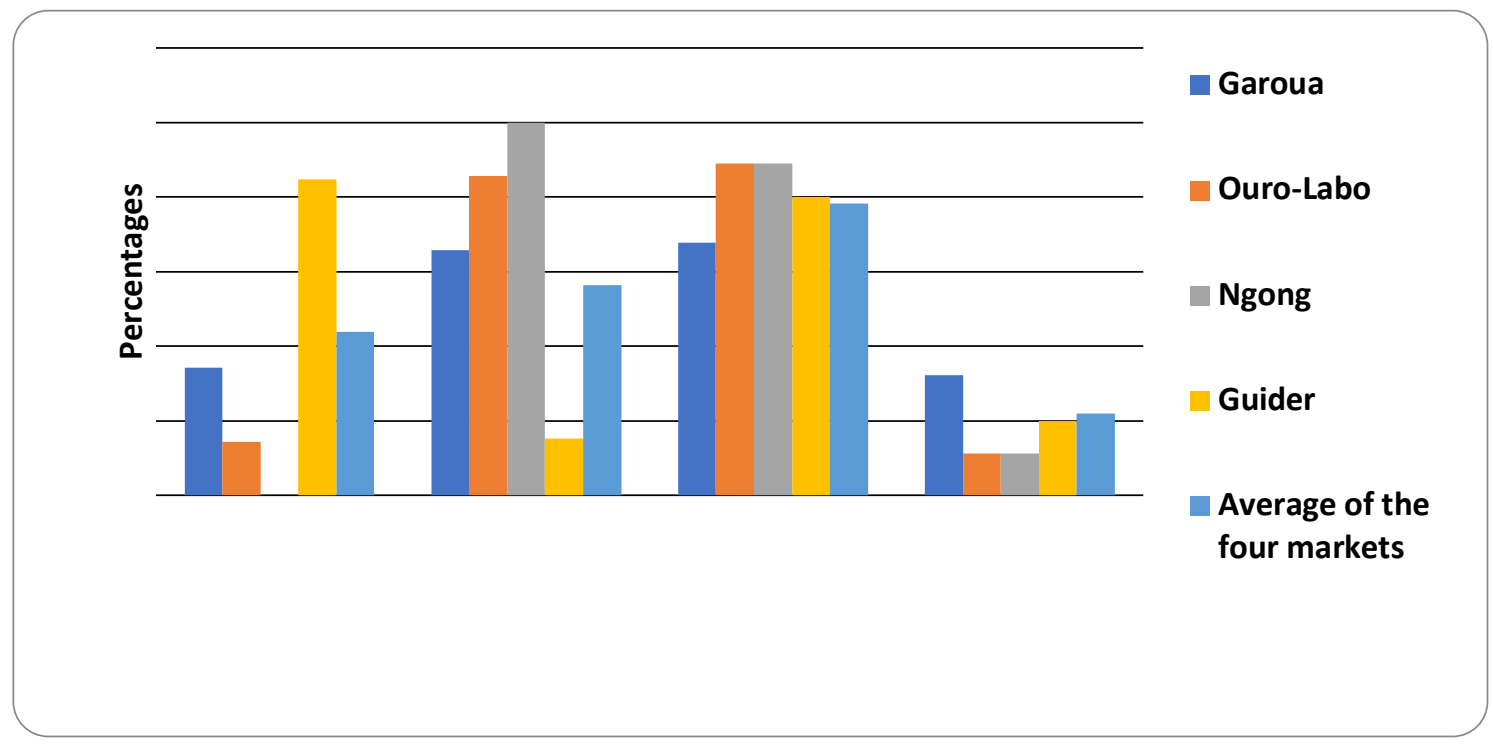

\footnotetext{
Figure 3: Percentage distribution of frequency of accessibility to improved varieties (IVs)
}

Figure 3 shows that a significant percentage (57\%) in the four markets claimed not to have frequent access to IVs of food legumes, while (43\%) did so. A significant percentage $(78 \%)$ across the four markets claimed they sorted contaminated grains from healthy ones. This was a task manually performed by women at home and market. Observation shows majority of retailers were involved in marketing at least three types of food legumes although in small quantities with not more than $100 \mathrm{~kg}$ being combined. Some retailers reported they bought estimated quantities from wholesalers on market day proper and sold on the same market This was an endogenous practice that vendors incorporated into their constraints (high cost of inputs, unpredictable climatic conditions, transportation, police harassment) to maximize profit. Retailers could make \pm 10000 FCFA profit bag/100 kg on weekly basis. A significant percentage (90\%) of vendors procured food legumes within the geographic and administrative jurisdiction, not more than $60 \mathrm{~km}$ distance. 

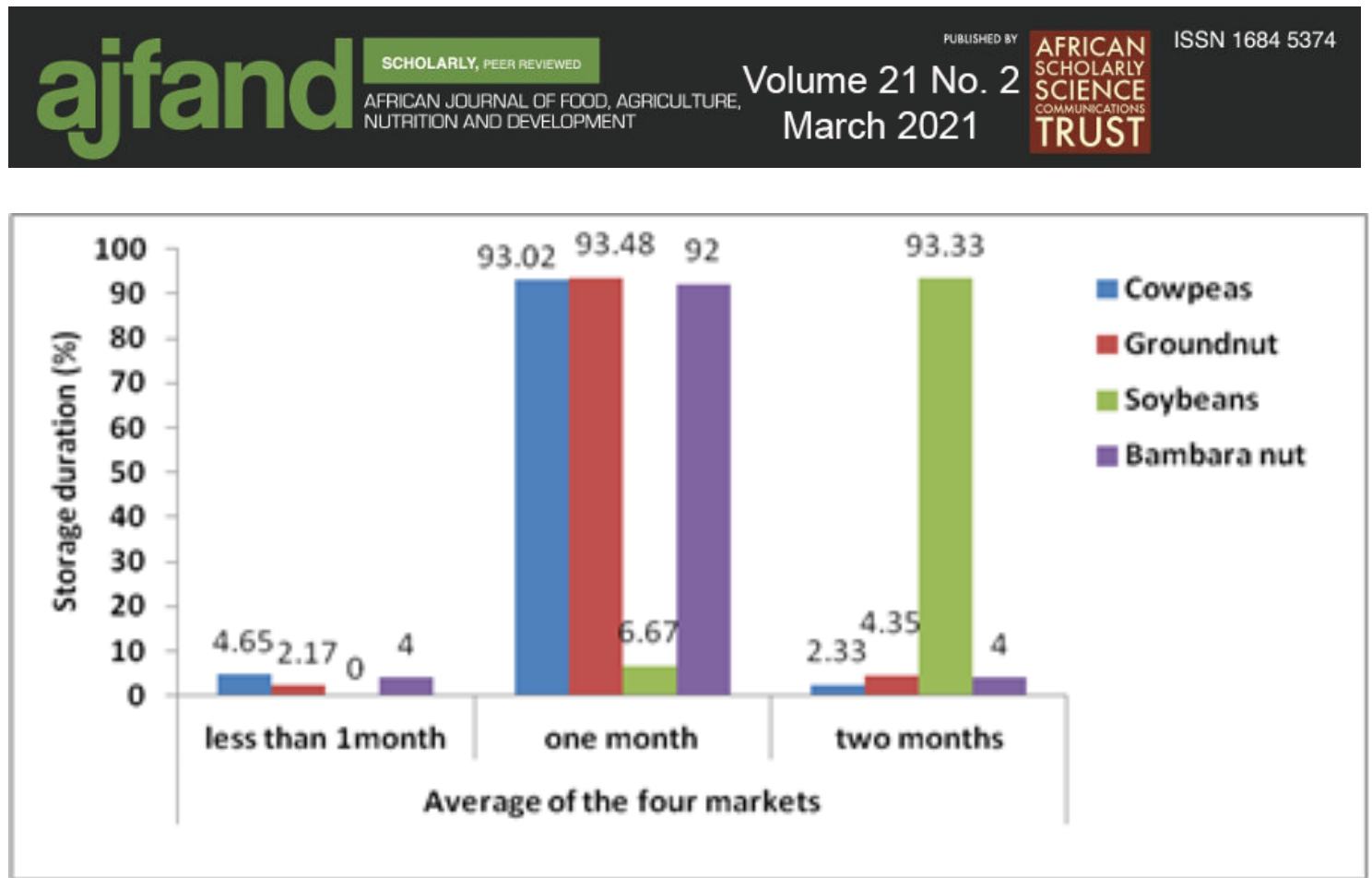

Figure 4: Percentage distribution of storage duration

Figure 4 shows low average duration of storages for food legumes not exceeding an average of two months. $93.02 \%$ of cowpea vendors, $93.48 \%$ of groundnuts vendors, and $92 \%$ of bambara groundnuts vendors stored for an average period one month. $93.33 \%$ of soybeans vendors stored for a duration of two months.

The formula for calculating the average storage duration is thus:

Formula

$\%$ vendors in the whole market storing a specific food legume during a specific duration

$$
\begin{gathered}
\text { Sum of the four markets vendors that store } \\
\text { a specific food legume for a specific duration } \\
\begin{array}{c}
\text { Sum of the vendors of the four markets } \\
\text { that store the specific food legume }
\end{array} \\
\text { irrespective of the duration of storage }
\end{gathered}
$$

Institutional support, coupled with the resistant nature of soybeans to weevils, contributed to the long duration of storage for soybeans. The cotton company (SODECOTON) promoted the cultivation of this exotic crop for industrial purposes.

In-depth analysis into these short durations of storage goes beyond the simplistic assumption of limited modern infrastructure and fee charges. Storing a bag of $100 \mathrm{~kg}$ of cereals and food legumes per month cost 100 FCA. Ngong and Lagdo markets had a capacity of 40 and 10 warehouse facilities with capacities of 300 and 100 bags/100kgs, respectively. Guider, Mayo-Oulo and Figuil sub-divisions had a total of 16 warehouse facilities with varying capacities from $100-1000 \mathrm{~kg} /$ per facility. The reasons for short duration of storage and post-harvest management are multidimensional: 1). transportation and storage fee charges, (2) sales to resolve daily problems (health, household necessities, school fees), (3) tradition and customary practices preventing women from controlling space (owning a warehouse and storage 


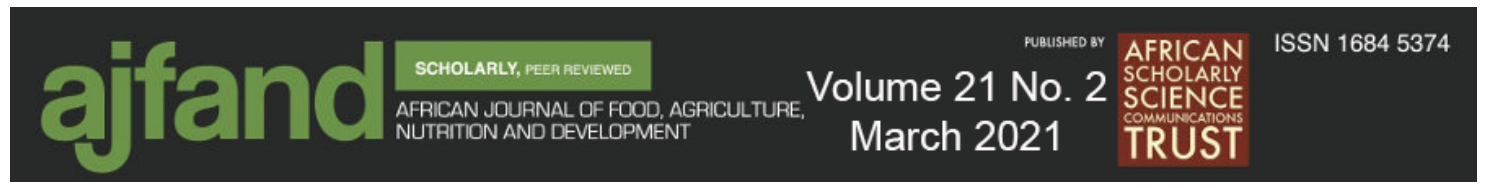

of large quantities of goods). A combination of these factors coupled with the climatic conditions and other factors had an influence on prices of cereals and food legumes on the markets.
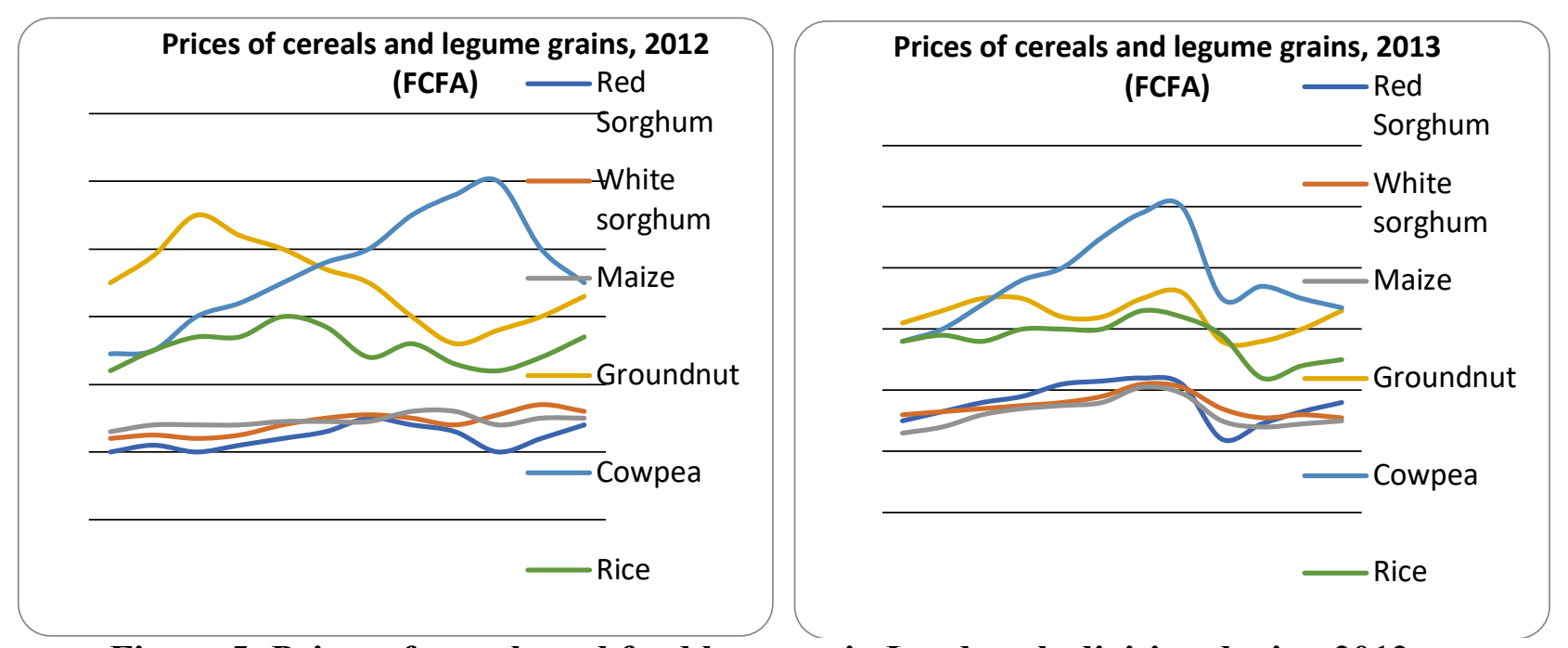

Figure 5: Prices of cereals and food legumes in Lagdo sub-division during 2012 and $2013[13,18]$

In Lagdo sub-division, prices of white sorghum were high compared to red sorghum in 2012. This might be explained by the fact that red sorghum is generally given more attention than white sorghum and is more intensively cultivated than white sorghum. Red sorghum is used for both household and local industrial activities in terms of local beer product (bil-bil). Women are engaged in these micro activities as a source of income. White sorghum is mostly used for household food consumption, though some varieties are used in manufacturing of local beer. Due to the importance of sorghum and red sorghum in particular, for socio-cultural activities, it is stocked throughout the year even in small quantities by households. There is excessive and wasteful use of sorghum as it is transformed in large quantities for ceremonial, cultural festivals and daily consumption. This most often compromises household and community food security and nutrition. Food legumes complement this nutritional gap. 


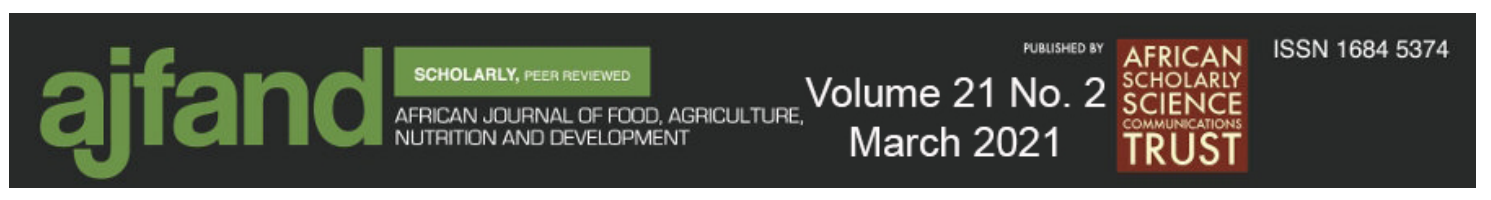

Prices of cereals and legume grains, 2012
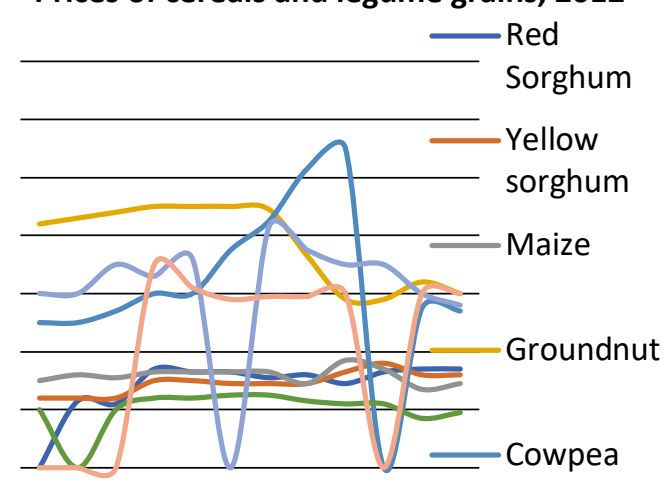

Paddy rice

Prices of cereals and legume grains, 2013
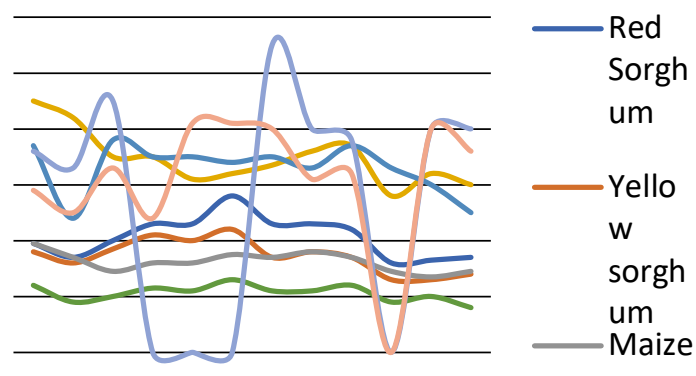

Figure 6: Prices of cereals and food legumes in Tcheboa sub-division, 2012 and $2013[19,20]$

There were increases in prices of cereals than food legumes in 2013 as compared to 2012. This can be attributed to erratic rainfall in 2013. Prices of cereals are lower than prices of food legumes with the exception of sesame which has increased prices more than groundnuts. Sesame is used for sauces and medicinal purposes. The increased price in markets of the North region is explained by the fact that knowledge of sesame cultivation belongs to Mafa peoples. This explains the reason why sesame is found in small quantities in the market.

Sorghum is produced twice a year (rainy season and dry season). The rainy season sorghum is cultivated in May and harvested in September. Muskwari sorghum is planted in September and harvested during the month of December and January. Erratic rainfall and other factors combined contributed to low production output of cereals, thus increased prices as compared to food legumes. The rotation and intercropping of food legumes and cereals is important to increase soil fertility and promote smallholder farming in the Sudano-Sahelian zone of Cameroon.

Price fluctuations between food legumes and cereals are conditioned by internal and external market forces of demand and supply. For example, the month of August, which is expected to be the peak period of scarcity, the price for groundnuts is 30000 FCFA $/ 100 \mathrm{~kg}$. In anticipation of increased prices, traders release the old stock to avoid incurring losses. This explains the decrease in prices of groundnuts by $26000 \mathrm{FCFA}$ in September which is the period of harvest. 

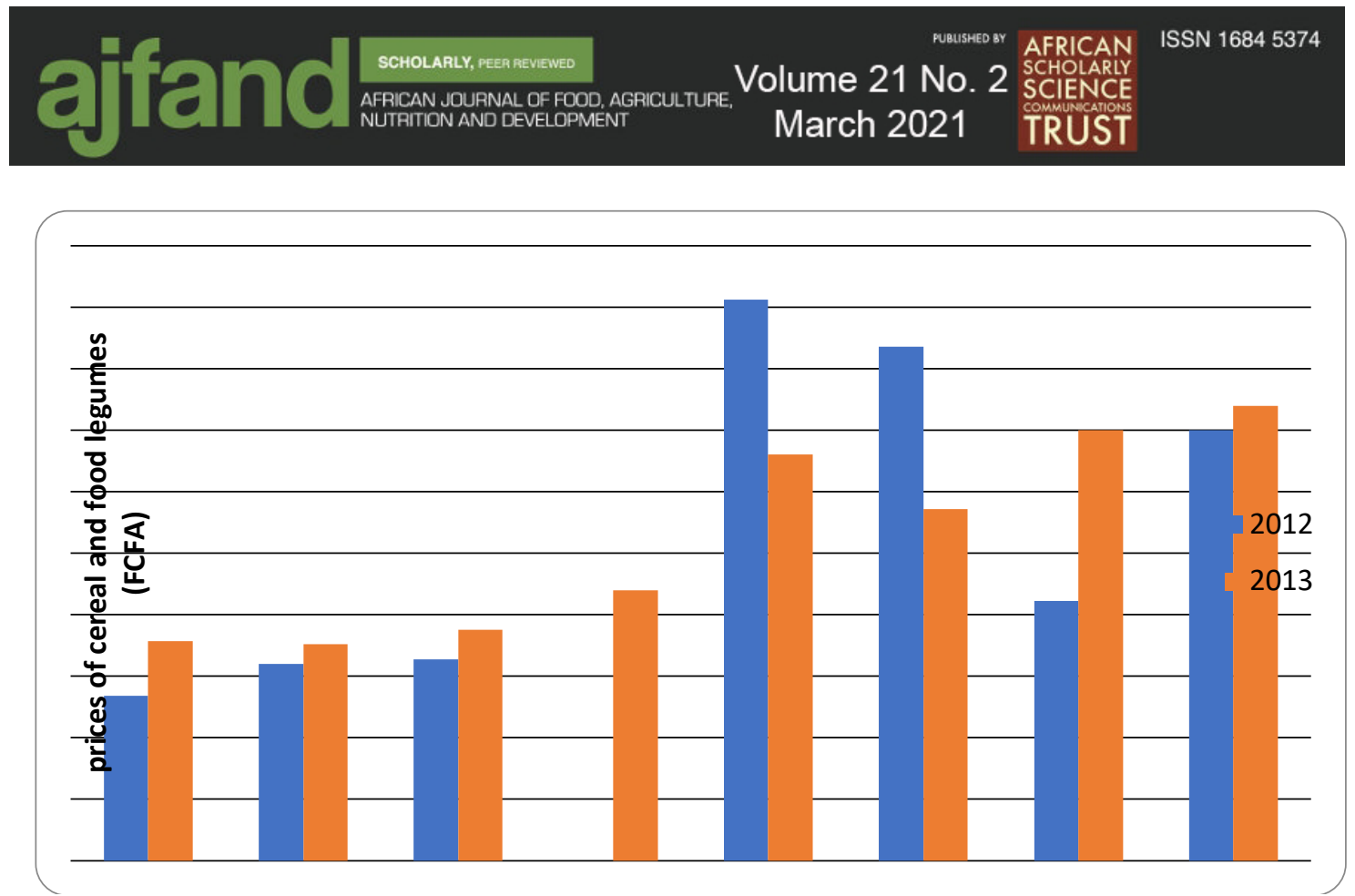

Figure 7: Prices of cereals and food legumes in Guider sub-division during 2012 and 2013 [12]

Fig. 7 shows a significant difference in the average prices of food legumes and cereals in 2012 and 2013 in Guider sub-division. The absence of market prices of soybeans in the MINADER data is explained by the fact that soybeans is not only a new crop being introduced in the region but the value chain was more 'structured' and 'organized' by the SODECOTON company.

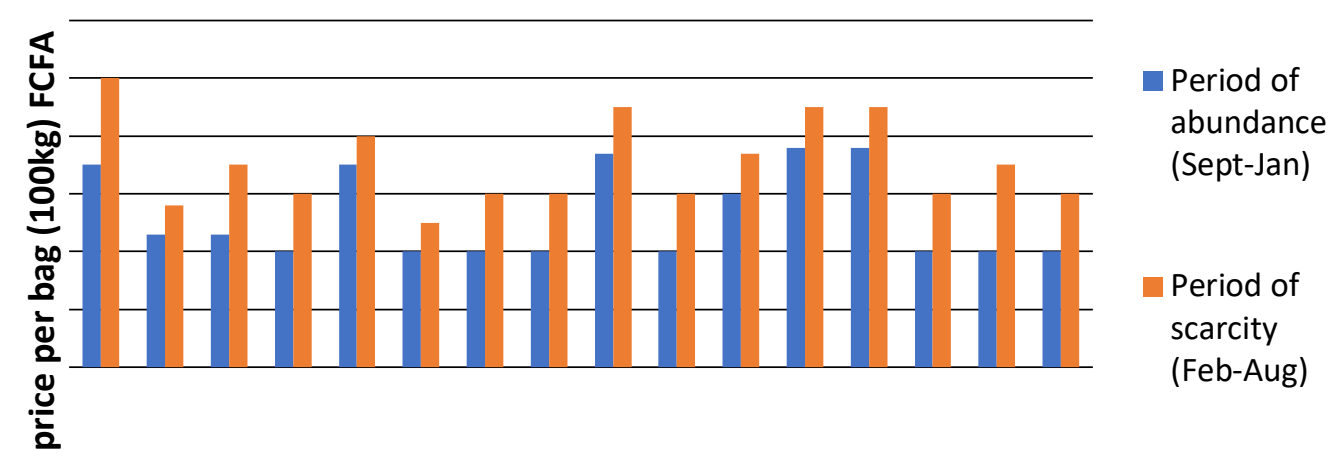

\section{Figure 8: Period of abundance and scarcity for prices of food legumes}

The high prices of groundnuts during the period of abundance compared to the previous years are linked to the high demand for both the local and improved varieties (local and external markets) as they are used for several purposes (household and industrial uses). From Fig. 8 there are low prices during the month of September. During the first months of harvest, farmers sell their products to meet immediate 


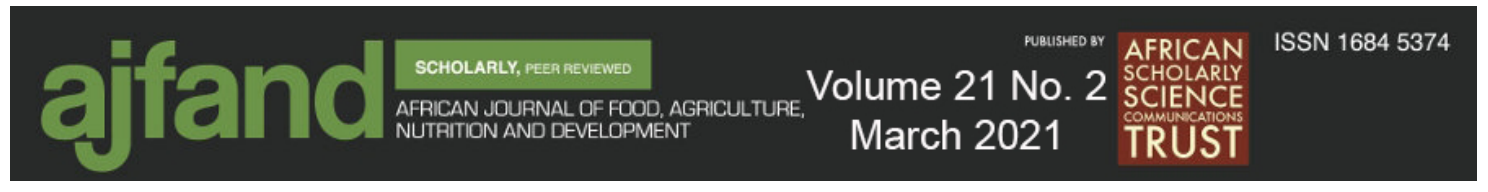

household needs and to repay credit. During periods of abundance, prices of groundnuts in convergent peri-urban markets of Guider and Ngong are 38000 FCFA and 37000 FCFA, respectively. These markets are strategically situated in the northern and eastern parts, linking the southern part of the country and neighbouring countries such as Chad, Gabon, Equatorial Guinea, and Nigeria. The Ouro-Labo market which is about $15 \mathrm{kms}$ from the Garoua Central market furnishes wholesalers and retailers; this might explain why there is no significant difference in price. During the period of scarcity, prices increased to about 45000 FCFA in the three peri-urban markets and 50000 FCFA in Garoua urban market.

Traders stock food legumes from Ngong markets and resale them at higher prices when there is scarcity. This explains why retailers in Garoua central market procure from the weekly Ouro-Labo and Pitoa, Takasko peri-urban markets which are situated about $15 \mathrm{kms}$ from Garoua urban market. This explains the fact that at certain periods of the year groundnut is cheaper in the southern parts of Cameroon than in Garoua that is furnished with modern infrastructure.

\section{Storage infrastructure deficit in perspective}

The issue of storage infrastructure deficit is a social, structural and institutional problem as revealed in the study. The majority of respondents claimed they stored 1-5 bags $/ 100 \mathrm{~kg}$ for all the food legumes. This constituted $63 \%$ of respondents for cowpeas, $72 \%$ for groundnuts, $82 \%$ for soybeans and $93 \%$ for bambara groundnuts. Research studies indicate that $80 \%$ of maize producers in Cameroon, Chad, and Central African Republic (CAR) produced 4 to 50 bags of $100 \mathrm{~kg}$, which does not encourage the refurbishment of sustainable structures, because early sales and production jolts which follows from the first month of harvest (October and November), impose short storage duration (3 to 10 months). This might be a determinant factor in the persistence of traditional storage systems, in spite of the strong efforts in modernising the storage system through diverse public and private projects and programmes. The increasing orientation of grain production confers the conservation of harvested crops in rural areas of Africa an important place in preservation of food security, as there is the necessity to ensure conservation and utilisation of grains until the next farming season [5].

To avoid huge exposure to pest, disease and rodents, smallholder farmers stored grains in pods and decorticated quantities, and is only decorticated a few days prior to being sold in the market. Traders multiply displacements on rural markets, thus repercussions on the cost of constituted stocks for urban markets. The duration of storage, stock fees, and losses due to pest infestations, explains the increased prices of cowpeas compared to maize in Cameroonian markets [5]. Sun drying of legume and cereal grains on the farms is a common method of conservation in North Cameroon. The "danki" is a traditional mat used in the drying of food legumes. Some farmers have adopted exogenous methods of storage using treated bags "SAC PIC" which cost 1200 FCFA ( 6 months conservation period). Furthermore, wholesalers complained that there were several companies in charge of producing bags and there were inaccuracies in terms of actual kilograms. 


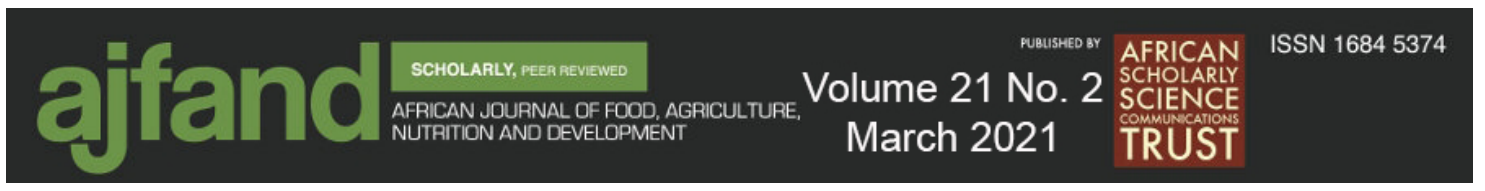

\section{Performance of food legumes: commercial channels in perspective}

The commercialization of food legumes takes three principal supply channels- towns of North Cameroon (Ngaoundere, Garoua, Maroua and Kousseri), cities in the southern part of Cameroon (Yaoundé, Douala, Bafoussam), and the neighbouring countries (Nigeria, Chad, CAR, Gabon, Equatorial Guinea). The absence of official statistics does not allow understanding the proportion of external flows; however, field observations attest by the intensification of these flows, a detriment to local markets. This might pose a problem relating to the mastery of the availability of local supply, and consequently the preservation of food security at the regional level.

However, the following are estimates of export and local consumption as reported: Nigeria (30\%), Bangui, Chad, Congo, Gabon (20\%), Douala, Yaoundé, Bafoussam, Bamenda (40\%), and Garoua, Kousseri, Maroua (10\%). The lack of control measures on the part of state authorities explains partly the increase in prices of food legumes at certain periods compared to cities in the southern part of the country. Intervention measures from the state could limit these flows to ensure food sufficiency and nutrition in this very fragile ecology. The prices of food legumes depend on the destination.

The political instability and social unrest in the Central African Republic (sectarian conflict) impacted negatively and positively on the performance of the commercial system and consumption patterns locally and regionally. This explains the decreased prices of food legumes when the frontiers of neighbouring countries like Gabon, Nigeria, and Central African Republic are closed. The influx of refugees from the Central African Republic had also put pressure on food consumption and distribution channels.

\section{Socio-cultural barriers}

Marginalization, the restriction of land ownership by traditional tenure and poor distribution of land for agriculture are some of the main constraints faced by women and girls in local communities of North Cameroon. The impediments of women's empowerment include their lack of access to the decision-making process, low participation in local governance, and limited access to technology inputs and credit. Traditional practices forbid women and girls to have or manage large amounts of money. Such restrictions have serious consequences on agricultural production. Instead of exploiting the productive capacity of women at all levels, including food production and processing, some of the traditions simply stifle their potential energies.

Since women are not independent, it is difficult to involve them actively in searching information concerning issues of price fluctuations and peak periods to stock and release their stock. The cultural environment is a greater deterrent to entry into this entrepreneurial activity rather than the capital. It was revealed during the focus group discussions that two courageous women in Figuil Sub-division had ventured into the wholesale sector of food legumes but pulled out after a few years. The cultural factors rather than the physical force required for this activity can be an explicit factor. 


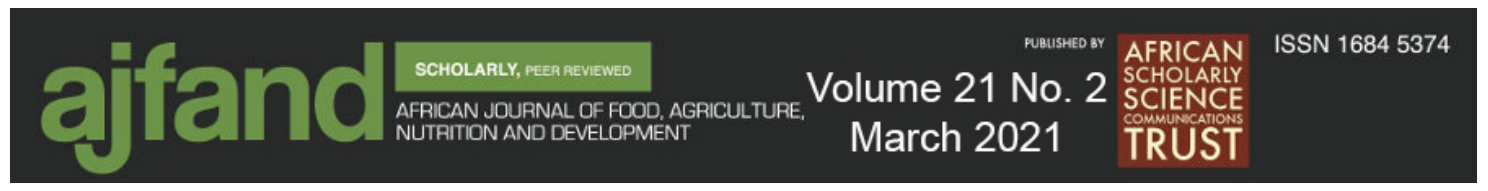

Women faced enormous constraints in processing as there was drudgery in the manual tasks and exposure to heat. The Food Technology Programme in the Institute of Agricultural Research for Development in Garoua has recently organized training workshops to build capacity of women in processing of food legumes. However, past experience with other technologies diffused such as the processing of fruits into juice and natural nectars were not fully adopted in the local communities.

\section{Credit market and capital}

Field observations and discussions revealed that the credit market is highly segmented. The simplistic and generalized assertion of inadequacy of credit infrastructures is more of a social-structural than an institutional problem. Women especially in the rural areas are not often aware of the existence of these credit infrastructures. Therefore, even if access to credit by women at the level of micro and small-scale enterprise was facilitated through innovative programs and financing arrangements went beyond the conventional approaches; it is doubtful this might dismantle the stereotype on women to become entrepreneurs in the current status-quo. The monopoly of Crédit Sahel as a micro-finance agency might not be totally gender inclusive and flexible concerning loans for agriculture. The gender and social class of farmers that Crédit Sahel supports with credits though on high interest is not elaborated in the official report of MINADER.

The credit market within the Credit Sahel agency itself is much segmented and void of formalized arrangements. The timely compilation of documents for loans should begin by the month of February so that credit is available to farmers on time. The high interest rate is a handicap to farmers because of low levels of soil fertility. Farmers repay loans under pressure, thus sell their produce cheaply to avoid increasing interest [13]. In effect, wholesalers give goods to retailers who after sale pay at wholesale price per $100 \mathrm{~kg} / \mathrm{bag}$. These forms of relations based on trust exist also between transporters, wholesalers, transporters and retailers. The latter gives money to transporters who buy goods where the prices are relatively low. However, this relationship of trust among 'middlemen' is manifested mostly based on affinity (friendship, kinship).

\section{Lack of coordinated action, poor transport and road infrastructure}

There were no cooperatives involved in the commercialization of food legumes. The study revealed complex relations in the marketing sector based on trust and affinity (friendship, clan, and lineage). Motorbikes are the common means of transportation from the hinterland to the peri-urban and urban markets. This transportation difficulty due to poor state of roads is a classical African constraint $[5,16]$. The distance and poor road network to market destination (approximately $1500 \mathrm{kms}$ ) from the North region to the southern part of the country and neighbouring countries is a huge constraint especially during the rainy season. Food legumes can perish as a truck could take four days and sometimes a week due to breakdowns to arrive in the southern part of the country and neighbouring countries. Marketing knowledge innovation refers to creation of new products and services to serve new markets, enabling coordinated action among individuals and organisation members to expand its market base or range of beneficiaries. Innovation in business can be a change in 


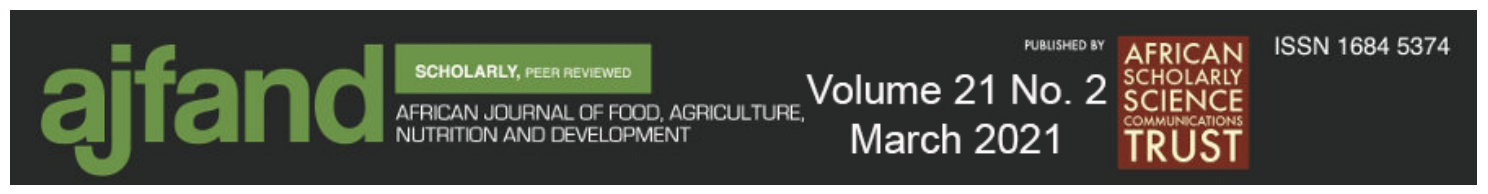

working methods, such as group or teamwork, and is not always enabled by technologies [17].

\section{CONCLUSION}

The study revealed that the production and commercialization of food legumes is constrained by social, structural, institutional, agro-pastoral conflicts, agronomic, environmental and climatic factors. To fight poverty, food insecurity and nutritional deficiencies in the northern region, the pivotal place of women in society needs to be accepted and supported. Women need capacity building and training in functional areas such as finance, literacy skills, marketing, production and managerial skills. A change of mind-set and mind shift among their spouses (and among men in general) and traditional authorities should also be encouraged so that they give full support besides embracing the changing role of women in the homes. Married women should be given support by their spouse in respect of finances, motivational encouragement, advice and actual involvement in the running of business. Women and youths have to expand their market and become competitive beyond the community level.

Cooperatives could reduce the marketing cost involved in the various chains (for example, access to information on new varieties, market prices and certification).

\section{ACKNOWLEDGEMENTS}

We thank all our co-researchers (respondents) for participating in the study and the French Government for providing funding through the Debt Relief Initiative (C2D). We also thank MINADER and IRAD in facilitating data collection. 


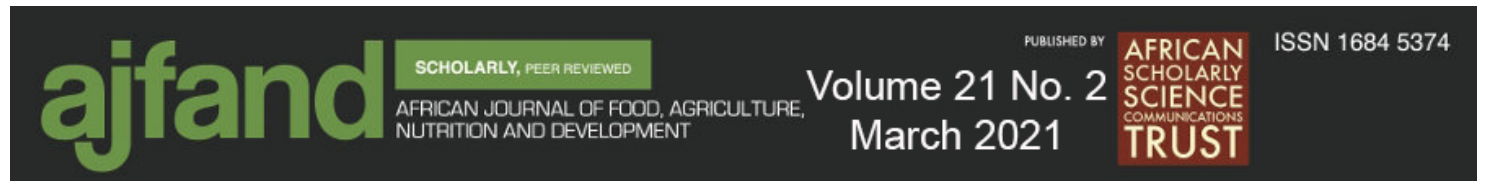

\section{REFERENCES}

1. Akibode $\mathbf{S}$ and $\mathbf{M}$ Maredia "Global and regional trends in production, trade and consumption of food legume crops", Department of Agricultural, Food and Resource Economics, Michigan State University, 2011; 2.

2. Asian Productivity Organization Report. Proceedings of seminar on processing and utilization of legumes, held in Japan on 9 - 14 October 2000.

3. Hillocks RJ, Bennett $\mathbf{C}$ and OM Mponda Bambara nut: A review of utilisation, market potential and crop improvement, Journal of African Crop Science, 20 (1): 2012; 1-16.

4. Carsky RJ, Douthwaite B, Manyong VM, Sangina N, Schulz S, Vanlauwe B, Diels $\mathbf{J}$ and JDH Keatinge Amélioration de la gestion, des sols par l'introduction de légumineuses dans les systèmes céréaliers des savanes africaines. Cahiers Agriculture 2003; 12 (4): 227-233.

5. Ndjouenke R, Nzossie JF, Kouebou C, Njomaha C, Grembombo AI and KM Oudanan «Le maïs et le niébé dans la sécurité alimentaire urbaine des savanes d'Afrique Centrale» Projet ARDESAC, Appui à la Recherche Régionale pour le Développement Durable des Savanes d'Afrique Centrale); 9-11.

6. IRAD. Semence améliorées des principales spéculations en appui à la campagne agro-sylvo-pastorale, 2010; 28pp.

7. IRAD/SODECOTON. Fiche technique soja. IRAD/SODECOTON. Garoua, Cameroon 2009; 2.

8. Leroy $\mathbf{J}$, Nchoutnji I and $\mathbf{O}$ Nopelba Cultures de diversification du coton: Présentation du soja et du tournesol. Communication à la Restitution des Résultats de recherche en convention IRAD/SODECOTON Campagne 2011-2012. Salle de Réunion de la SODECOTON, Garoua, 19 - 20 Avril 2012.

9. Mekontchou T, Ngueguim M and M Fobasso Stability for yield and yield components of selected peanut breeding lines (Arachis hypogaeae L.) in the North Province of Cameroon. Tropicultura, 2006; 24 (2): 90-94.

10. Essang $\mathbf{T}$ Diagnostic de la filière arachide au Cameroun, IRAD/PRASAC, IRAD Garoua, Cameroon. 2000.

11. Sketch Map of Departments in the North Region of Cameroon. (Available at: http://en.academic.ru/dic.nsf/enwiki/11633129 (accessed on September 17, 2014).

12. MINADER Report, Divisional Delegation, Mayo-Louti, Cameroon 2012.

13. MINADER Report, Sub-divisional Delegation, Lagdo, Cameroon 2013. 


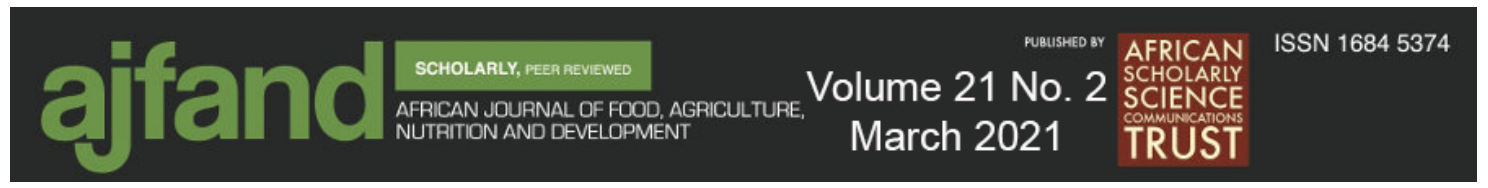

14. Defang NJ, Manu I, Bime MJ, Tabi OF and HF Defang Impact of Climate Change on Crop Production and Development of Muyuka SubdivisionCameroon. International Journal of Agriculture, Forestry and Fisheries, 2014; 2(2): 40-45.

15. Berelson B Content Analysis in Communication Research, New York: Hafner Publishing Company, 2000.

16. Mokeona MA, Kaya HO and A Buabeng African Indigenous Entrepreneurial Activities among Batswana Women. In: Smith JA and MA Masoga (Eds.). African Indigenous Knowledge Systems and Sustainable Development. People's Publishers Durban, 2012; 257-270.

17. What is marketing Innovation? Available at http://libweb.surrey.ac.uk/library/skills/Innovation\%200U/B202_2_section1.htm (Accessed 13, February 2015).

18. MINADER Report, Sub-divisional Delegation, Lagdo, Cameroon 2012.

19. MINADER Report, Sub-divisional Delegation, Tcheboa, Cameroon 2012.

20. MINADER Report, Sub-divisional Delegation, Tcheboa, Cameroon 2013. 